\title{
Patterns of recruitment and resource use in a shallow-water fish assemblage in Moreton Bay, Queensland
}

\author{
K. Warburton ${ }^{1}$, S. J. M. Blaber ${ }^{2}$ \\ ${ }^{1}$ Department of Zoology, University of Queensland, St. Lucia, Queensland 4072, Australia \\ ${ }^{2}$ CSIRO Division of Fisheries, PO Box 120, Cleveland, Queensland 4163, Australia
}

\begin{abstract}
Seven shallow-water sites in the western part of Moreton Bay, Queensland, Australia, were sampled by beam trawl on 7 occasions during 1987 and 1988. The sites differed significantly in their macrophyte and loose shell cover. The most abundant fish species was cardinal fish Apogon fasciatus, followed by fan-bellied leatherjacket Monacanthus chinensis, leatherjacket Paramonacanthus otisensis, trumpeter Pelates quadrilineatus and pony fish Leiognathus moretoniensis. Other species were comparatively rare. Small juveniles of the 5 species recruited to the area, with all except $L$. moretoniensis being most abundant at the most vegetated site. Mean catch rates differed significantly between sites, and patterns of habitat use, seasonality and diel behaviour varied between species There was evidence of ontogenetic migration into deeper water in all species, although this was weakest for $A$. fasciatus. Diets of the 5 species were distinguished by gravimetric, numerical and occurrence techniques: $P$. quadrilineatus and $L$. moretoniensis took large amounts of polychaetes and copepods, $M$. chinensis and $P$. otisensis consumed more amphipods, molluscs and vegetation, and $A$. fasciatus exploited a wide size range of prey, including crabs, fish and small crustaceans. Interspecific diet overlap was greater in larger fish, but was less than intraspecific overlap between size classes. Daytime feeders dominated the assemblage, but catch rates were higher at night. Overall patterns of resource use suggested species partitioning, but strong evidence of niche separation was obtained only for $L$. moretoniensis, which was distinct on all 3 major resource axes (food, habitat and time). Therefore, scope existed for interspecific competition between members of the assemblage.
\end{abstract}

\section{INTRODUCTION}

There is some evidence that, in contrast to the situation with terrestrial vertebrates, food partitioning is more important than habitat partitioning in fish assemblages (Schoener 1974, Ross 1986). However, only a few fish studies have examined the relative importance of habitat, food and temporal partitioning (Ross 1986). More information is also needed on ontogenetic changes in resource use (Ross 1986). For example, despite the importance of shallow vegetated habitats as centres of fish recruitment, knowledge of links between habitats and trophic patterns is limited by the lack of quantitative fish community studies and trophic studies in seagrass and mangrove habitats (Parrish 1989).

This paper examines the roles of spatial, food and temporal partitioning in relation to ontogenetic changes in habitat preferences and diet of the $5 \mathrm{nu}$ merically dominant species of both vegetated and nonvegetated habitats in Moreton Bay, Queensland, Australia. Moreton Bay is a large, subtropical estuary supporting a diverse fauna and an important mixed fishery (Williams 1980, Stephenson \& Williams 1981, Pollock \& Williams 1983). These dominant fish species are also abundant in all northern Australian waters (Stephenson et al. 1982b, Rainer 1984, Blaber et al. 1990). In spite of the role of the smaller benthic fish species as secondary consumers and as food for commercial fishes (Grant 1982), birds (Blaber \& Wassenberg 1989) and marine mammals (Wassenberg \& Hill 1989), studies of their ecology are few and have been concerned mainly with descriptions of large-scale distribution and seasonality (e.g. Young \& Wadley 1979 , Stephenson et al. 1982a, b). 

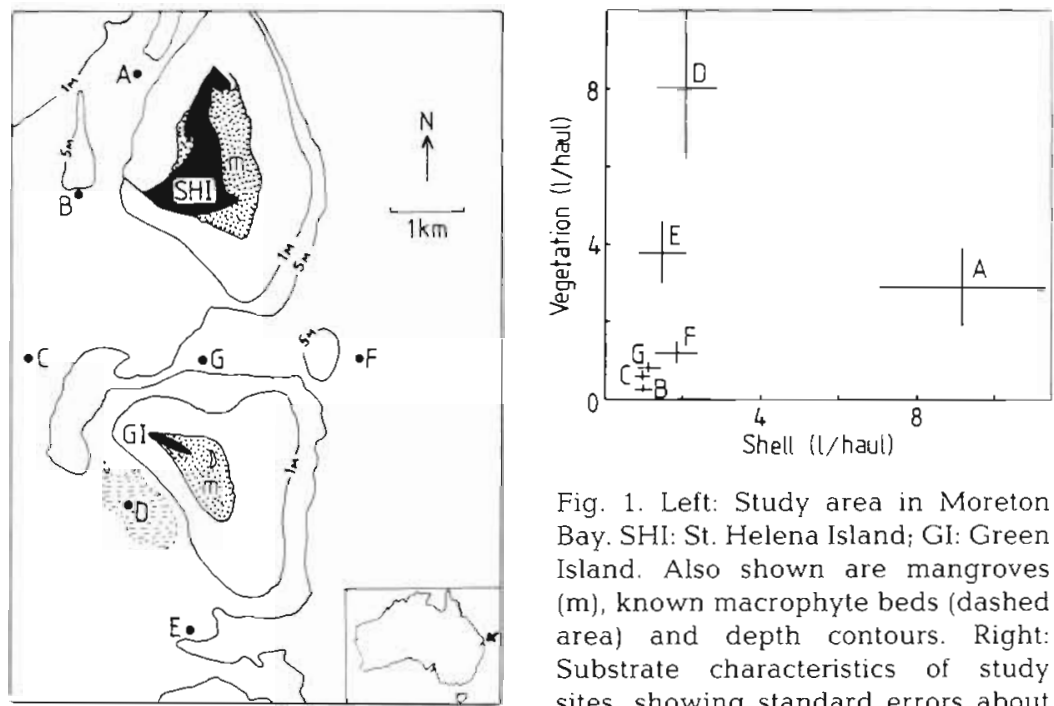

Fig. 1. Left: Study area in Moreton Bay. SHI: St. Helena Island; GI: Green Island. Also shown are mangroves (m), known macrophyte beds (dashed area) and depth contours. Right: Substrate characteristics of study sites, showing standard errors about means [volumetric measure: l (beam trawl haul) "I

ence (general linear model, SAS). Population cohorts were separated by polymodal length-frequency analysis (Cassie 1954). Instantaneous rates of numerical decline were estimated as the slopes of regressions of $\log _{e}$ (cohort density) against time. Ontogenetic dietary trends were examined after individuals of each species were separated into 2 arbitrary size classes: 'small' $(<5 \mathrm{~cm})$ or 'large' $(>5 \mathrm{~cm})$. Diets were classified by cluster analysis using the Bray-Curtis dissimilarity measure and group-average sorting. Diet breadth was measured by Levins (1968) formula, $B=\left(\sum p_{i}^{2}\right)^{-1}$, where $p_{i}$ $=$ the proportion of each prey category in the diet. Resource overlap was estimated using Schoener's (1968) measure, $D=1-0.5 \sum_{i=1}^{n}\left|p_{x_{1}, i}-p_{y_{1}}\right|$, where $n$ $=$ no. of resource states, $p_{x_{1},}=$ propor tional use by species $x$ of resource state $i$, and $p_{y, i}=$ proportional use by

\section{METHODS}

Fish sampling was carried out at 7 sites near St. Helena and Green Islands in Moreton Bay. The study area was small enough to minimise population isolation yet large enough to provide significantly different habitats. The sites were sampled every 2 mo between August 1987 and August 1988 inclusive, close to the first lunar quarter in all but 1 instance (the June 1988 sampling was postponed to July). Hauls of $10 \mathrm{~min}$ duration were made with a beam trawl $(3 \mathrm{~m}$ beam; headline-codend distance $5 \mathrm{~m}_{i}$ stretched inside mesh $21 \mathrm{~mm}$ ), operated from a $15 \mathrm{~m}$ trawler. On each trip hauls were made at each site (A to $G$ in order; Fig. 1), 2 circuits being made by day and 2 by night (i.e. $7 \times 2 \times 2=28$ hauls per trip). The standard length of all fish was measured. Subsamples of each species (up to 30 for each site-trip combination, depending on abundance) were promptly frozen on board and their gut contents later quantified gravimetrically, numerically and in terms of the proportion of the predator population in which a given prey type occurred (Hyslop 1980). Most of the diet analysis was carried out by 1 person. Trawled macrophytes and shell debris were quantified volumetrically using a 21 container.

Catches were pooled to give 7 site-day and 7 sitenight totals per trip. The numbers of individuals were $\log$-transformed $\left[\log _{10}(n+1)\right]$ to stabilise the variance (Taylor 1953, Elliott 1977). Catch rates, gut fullness and the abundance of each prey category in the gut by site, trip and time of day were compared by 3-way ANOVA. and multiple range testing, using least-squares differ- species $y$ of resource state $i$. Unlike some other overlap measures, Schoener's $D$ estimates overlap adequately over most of the potential range (Linton et al. 1981) and can be applied in the absence of resource availability data (Hurlbert 1978, Wallace 1981). Overlap was taken to be significant when $D>0.6$ (Zaret \& Rand 1971, Mathur 1977) and the criterion for significant separation was taken to be $D<0.4$, following Ross (1986). Diet breadth and overlap calculations were only performed on predator groups from which more than 50 diet individuals were obtained. The spatial and temporal evenness of mean catches was represented using Shannon's index (Pielou 1966).

\section{RESULTS}

\section{Study area}

Mean water depths at the times of sampling varied little between sites, ranging from $5.0 \mathrm{~m}$ at Site $D$ to $7.6 \mathrm{~m}$ at Site F. Bottom temperature and salinity were also consistent between sites (within $1{ }^{\circ} \mathrm{C}$ and $2 \mathrm{ppt}$ respectively), but showed distinct seasonal cycles. Mean temperature reached a peak of $26.3^{\circ} \mathrm{C}$ in February and a low of $18^{\circ} \mathrm{C}$ in June-August 1988 ; salinity averaged $34 \mathrm{ppt}$ in October-December but fell to 28.5 ppt by June-July. Sediments were largely of muddy sand (Maxwell 1970 and pers. obs.), often covered by scattered shell fragments. Material collected in the trawls indicated that Site D had the densest cover of macrophytes (mainly seagrass Halophila spinulosa 
Table 1. Mean catch per unit effort (no. haul ${ }^{-1}$ ) for the 5 dominant fish species by site, time of day and trip, with standard errors Groups that did not differ significantly (ANOVA on log-transformed data, Table 2) are given the same number in parentheses (low values $=$ high mean catches)

\begin{tabular}{|c|c|c|c|c|c|c|c|c|}
\hline \multirow[t]{2}{*}{ Species } & & \multicolumn{7}{|c|}{ Site } \\
\hline & & A & B & $\mathrm{C}$ & $\mathrm{D}$ & E & F & $\mathrm{G}$ \\
\hline \multirow[t]{3}{*}{ Apogon fasciatus } & $\bar{x}$ & 2.11 & 13.46 & 8.88 & 63.19 & 24.88 & 4.67 & 7.25 \\
\hline & $\mathrm{SE}$ & 0.44 & 2.89 & 2.22 & 11.99 & 6.14 & 1.72 & 1.36 \\
\hline & & (3) & (2) & (3) & $(1)$ & (2) & (3) & (3) \\
\hline \multirow{3}{*}{ Paramonacanthus otisensis } & $\bar{x}$ & 4.00 & 0.39 & 0.35 & 4.38 & 2.35 & 0.54 & 1.04 \\
\hline & SE & 1.32 & 0.13 & 0.14 & 1.33 & 0.80 & 0.16 & 0.23 \\
\hline & & (1) & $(2)$ & $(2)$ & (1) & (1) & $(2)$ & $(2)$ \\
\hline \multirow[t]{3}{*}{ Monacanthus chinensis } & $\bar{x}$ & 2.62 & 0.46 & 0.42 & 18.04 & 1.27 & 0.67 & 0.58 \\
\hline & $\mathrm{SE}$ & 0.76 & 0.12 & 0.18 & 4.01 & 0.48 & 0.28 & 0.24 \\
\hline & & $(2)$ & (3) & (3) & (1) & (3) & & \\
\hline \multirow[t]{3}{*}{ Leiognathus moretoniensis } & $\bar{x}$ & 1.04 & 7.14 & 3.92 & 4.08 & 2.58 & 1.50 & 3.82 \\
\hline & $\mathrm{SE}$ & 0.75 & 3.12 & 2.26 & 2.69 & 2.01 & 0.83 & 2.54 \\
\hline & & $(3)$ & (1) & (2) & $(2)$ & (3) & (2) & (2) \\
\hline \multirow[t]{3}{*}{ Pelates quadrilineatus } & $\bar{x}$ & 2.15 & 1.07 & 10.96 & 27.96 & 0.85 & 0.08 & 0.13 \\
\hline & SE & 1.23 & 0.96 & 5.68 & 11.03 & 0.54 & 0.08 & 0.09 \\
\hline & & $(3)$ & (3) & & & (3) & & \\
\hline \multirow[t]{2}{*}{ Species } & & \multicolumn{3}{|c|}{ Time of day } & & & & \\
\hline & & Day & Night & Overall & & & & \\
\hline \multirow[t]{2}{*}{ A. fasciatus } & $\bar{x}$ & 17.12 & 19.04 & 17.99 & & & & \\
\hline & SE & $\begin{array}{l}4.24 \\
(2)\end{array}$ & $\begin{array}{l}3.84 \\
(1)\end{array}$ & 2.88 & & & & \\
\hline \multirow[t]{2}{*}{ P. otisensis } & $\bar{x}$ & 1.54 & 2.27 & 1.87 & & & & \\
\hline & $\mathrm{SE}$ & $\begin{array}{l}0.40 \\
\text { (1) }\end{array}$ & $\begin{array}{l}0.56 \\
(1)\end{array}$ & 0.33 & & & & \\
\hline \multirow[t]{3}{*}{ M. chinensis } & $\bar{x}$ & 2.50 & 4.62 & 3.47 & & & & \\
\hline & SE & 1.05 & 1.40 & 0.86 & & & & \\
\hline & & (2) & (1) & & & & & \\
\hline \multirow[t]{2}{*}{ L. moretoniensis } & $\bar{x}$ & 1.22 & 6.22 & 3.50 & & & & \\
\hline & $\mathrm{SE}$ & 0.44 & 1.69 & 0.84 & & & & \\
\hline \multirow[t]{3}{*}{ P. quadrilineatus } & $\bar{X}$ & 4.96 & 7.79 & 6.25 & & & & \\
\hline & SE & 1.74 & 3.94 & 2.02 & & & & \\
\hline & & (1) & (1) & & & & & \\
\hline \multirow[t]{2}{*}{ Species } & & \multicolumn{7}{|c|}{ Trip (date, 1987-88) } \\
\hline & & 31 Aug & $27 \mathrm{Oct}$ & $23 \mathrm{Dec}$ & 24 Febr & $28 \mathrm{Apr}$ & $24 \mathrm{Jul}$ & $17 \mathrm{Aug}$ \\
\hline \multirow[t]{3}{*}{ A. fasciatus } & $\bar{x}$ & 4.86 & 18.25 & 7.00 & 11.79 & 25.57 & 25.00 & 26.75 \\
\hline & SE & 1.88 & 4.35 & 2.45 & 4.58 & 12.41 & 8.14 & 8.23 \\
\hline & & (2) & (1) & $(2)$ & $(2)$ & (1) & (1) & (1) \\
\hline \multirow[t]{3}{*}{ P. otisensis } & $\bar{x}$ & 1.14 & 0.50 & 3.56 & 2.89 & 0.86 & 2.89 & 1.71 \\
\hline & SE & 0.90 & 0.18 & 1.53 & 0.98 & 0.40 & 1.13 & 0.74 \\
\hline & & (2) & $(2)$ & (1) & (1) & $(2)$ & (1) & (2) \\
\hline \multirow[t]{3}{*}{ M. chinensis } & $\bar{x}$ & 1.86 & 2.25 & 1.39 & 2.89 & 5.89 & 4.79 & 4.11 \\
\hline & $\mathrm{SE}$ & 0.93 & 1.06 & 0.85 & 1.09 & 3.64 & 2.98 & 2.49 \\
\hline & & (1) & (1) & (1) & (1) & (1) & $(1)$ & (1) \\
\hline \multirow[t]{3}{*}{ L. moretoniensis } & $\bar{x}$ & 0.05 & 0.89 & 2.17 & 13.61 & 6.29 & 0.21 & 0.07 \\
\hline & $\mathrm{SE}$ & 0.05 & 0.32 & 0.80 & 3.73 & 2.35 & 0.15 & 0.07 \\
\hline & & (3) & (3) & (3) & $(1)$ & $(2)$ & (3) & $(3)$ \\
\hline \multirow[t]{3}{*}{ P. quadrilineatus } & $\bar{x}$ & 1.91 & 20.57 & 7.00 & 12.04 & 0.86 & 0.36 & 0.36 \\
\hline & SE & 1.40 & 7.88 & 4.51 & 9.01 & 0.51 & 0.29 & 0.26 \\
\hline & & (3) & (1) & (2) & (2) & (3) & (3) & (3) \\
\hline
\end{tabular}


and algae such as Hypnaea sp., Laurencia pygmaea, Sarconema furcellatum and Caulerpa mexicana), while shell debris was most prevalent at Site A (Fig. 1). High turbidities precluded detailed visual assessment of substrate or vegetation. The 7 sites differed significantly in terms of macrophyte cover and shell debris (Kruskal-Wallis test; $p<0.001$ for both). Multiple range testing (least significant difference, SAS $\mathrm{p}<0.05$ ) identified the following site groups, listed in decreasing order of abundance: D, EA, AFGC, FGCB (vegetation) and $A, D F E G B C$ (shell). Independent evidence for the existence of macrophyte beds in the region of

Table 2. Catch per unit effort for the 5 dominant fish species by site, time of day and trip: 3-way analysis of variance. Significance levels: ${ }^{*} p<0.05 ;{ }^{\prime} p<0.01$; $\cdots p<0.001$; ns: not significant. Analysis of log-transformed numbers per haul

\begin{tabular}{|c|c|c|c|c|}
\hline Species & $\begin{array}{l}\text { Source of } \\
\text { variation }\end{array}$ & $\mathrm{df}$ & $F$ & $\mathrm{p}$ \\
\hline \multirow[t]{7}{*}{ Apogon fasciatus } & Site & 6 & 33.51 & $\cdots$ \\
\hline & Time & 1 & 16.09 & $\cdots$ \\
\hline & Trip & 6 & 5.98 & $\cdots$ \\
\hline & Site $\times$ Time & 6 & 1.68 & ns \\
\hline & Site $\times$ Trip & 36 & 2.78 & $\cdots$ \\
\hline & Time $\times$ Trip & 6 & 3.86 & $\cdots$ \\
\hline & \multicolumn{2}{|c|}{ Overall model } & 7.89 & $\cdots$ \\
\hline \multirow[t]{7}{*}{ Paramonacanthus otisensis } & Site & 6 & 11.61 & $\cdots$ \\
\hline & Time & 1 & 2.70 & ns \\
\hline & Trip & 6 & 5.84 & $\cdots$ \\
\hline & Site $\times$ Time & 6 & 5.81 & $\cdots$ \\
\hline & Site $\times$ Trip & 36 & 2.17 & $\cdot$ \\
\hline & Time $\times$ Trip & 6 & 0.54 & ns \\
\hline & \multicolumn{2}{|c|}{ Overall model } & 3.93 & $\cdots$ \\
\hline \multirow[t]{7}{*}{ Monacanthus chinensis } & Site & 6 & 30.64 & $\cdots$ \\
\hline & Time & 1 & 14.77 & $\cdots$ \\
\hline & Trip & 6 & 0.42 & ns \\
\hline & Site $\times$ Time & 6 & 1.82 & ns \\
\hline & Site $\times$ Trip & 36 & 1.60 & ns \\
\hline & Time $\times$ Trip & 6 & 1.04 & ns \\
\hline & \multicolumn{2}{|c|}{ Overall model } & 5.12 & $\cdots$ \\
\hline \multirow[t]{7}{*}{ Leiognathus moretoniensis } & Site & 6 & 8.89 & $\cdots$ \\
\hline & Time & 1 & 29.41 & $\cdots$ \\
\hline & Trip & 6 & 50.92 & $\cdots$ \\
\hline & Site $\times$ Time & 6 & 0.67 & ns \\
\hline & Site $\times$ Trip & 36 & 2.54 & $\cdots$ \\
\hline & Time $\times$ Trip & 6 & 19.44 & $\cdots$ \\
\hline & \multicolumn{2}{|c|}{ Overall model } & 10.81 & $\cdots$ \\
\hline \multirow[t]{7}{*}{ Pelates quadrilineatus } & Site & 6 & 33.07 & $\cdots$ \\
\hline & Time & 1 & 0.42 & ns \\
\hline & Trip & 6 & 20.31 & $\cdots$ \\
\hline & Site $\times$ Time & 6 & 1.28 & ns \\
\hline & Site $\times$ Trip & 36 & 2.90 & $\cdots$ \\
\hline & Time $\times$ Trip & 6 & 0.22 & ns \\
\hline & \multicolumn{2}{|c|}{ Overall model } & 7.56 & $\cdots$ \\
\hline
\end{tabular}

Site D came from 1987 seagrass surveys (Hyland et al. 1989), satellite images and aerial photographs.

\section{Overall abundance}

The fish assemblage was dominated by 5 species: cardinal fish Apogon fasciatus (F. Apogonidae); leatherjacket Paramonacanthus otisensis (F. Monacanthidae); fan-bellied leatherjacket Monacanthus chinensis (F. Monocanthidae); trumpeter Pelates quadrilineatus ( $\mathrm{F}$. Theraponidae); and pony fish Leiognathus moretoniensis (F. Leiognathidae). Of these, A. fasciatus was 2.9 to 9.6 times more abundant overall than the other species (Table 1 ).

\section{Site use and iemporai variation}

Between-site variability exceeded between-trip variability in every species except Leiognathus moretoniensis, which was highly seasonal in occurrence. ANOVA revealed that the mean catches of all species varied significantly with site (Tables $1 \& 2$ ). $L$. moretoniensis was most abundant at the least vegetated site (B). All other species were most common at the most vegetated site (D); however, Paramonacanthus otisensis and Apogon fasciatus were much less restricted to this site than were Monacanthus chinensis and Pelates quadrilineatus (Table 1). The densities of all species except $M$. chinensis varied significantly between sampling trips and showed significant Site $\times$ Trip interactions (Tables $1 \& 2$ ). However, the seasonal patterns of elevated densities varied with species, these occurring in August 1988 (A. fasciatus), October $(P$. quadrilineatus), December ( $P$. otisensis), February (L. moretoniensis) and April ( $M$. chinensis). The relative abundance of A. fasciatus at the 7 sites varied with the season (Table 3), which, together with a significant sitetrip interaction in mean length, suggests that $A$. fasciatus undergoes an ontogenetic migration within the study area (Fig. 2). Site-trip interactions in mean length were not significant in the other species. Mean catches of $A$. 
Table 3. Apogon fasciatus. Catch matrix. Entries are mean $\log _{10}$ (no. haul ${ }^{-1}+1$ ) values. d: day; $n$ : night. Highest mean values for each site (day and night combined) in bold. Marginal values ( $\mathrm{n}>\mathrm{d}$ ) indicate frequencies when night mean catch exceeded day mean catch. nc: not calculated

\begin{tabular}{|c|c|c|c|c|c|c|c|c|c|c|c|c|c|c|c|}
\hline \multirow{3}{*}{ Month } & \multirow{2}{*}{\multicolumn{2}{|c|}{ A }} & \multirow{2}{*}{\multicolumn{2}{|c|}{$B$}} & \multirow{2}{*}{\multicolumn{2}{|c|}{ C }} & \multicolumn{4}{|c|}{ Site } & \multirow{2}{*}{\multicolumn{2}{|c|}{$F$}} & & & \multirow[t]{3}{*}{$\mathrm{n}>\mathrm{d}$} \\
\hline & & & & & & & & & & & & & \multicolumn{2}{|c|}{$\mathrm{G}$} & \\
\hline & $d$ & $n$ & $\mathrm{~d}$ & $n$ & $d$ & $\mathrm{n}$ & $\mathrm{d}$ & $\mathrm{n}$ & $\mathrm{d}$ & $\mathrm{n}$ & $\mathrm{d}$ & $n$ & $\mathrm{~d}$ & $\mathrm{n}$ & \\
\hline Aug & 0.0 & - & 0.3 & 1.3 & 0.0 & 0.7 & 0.5 & 1.3 & 0.2 & 0.8 & 0.7 & - & 0.6 & - & 1.00 \\
\hline Oct & 0.7 & 0.5 & 1.4 & 1.6 & 1.4 & 1.3 & 1.8 & 1.5 & 1.3 & 1.1 & 0.5 & 0.2 & 1.2 & 1.0 & 0.14 \\
\hline Dec & 0.0 & 0.7 & 1.0 & 0.9 & 0.7 & - & 1.4 & - & 1.1 & - & 0.0 & - & 0.7 & - & nc \\
\hline Feb & 0.5 & 0.6 & 1.0 & 1.2 & 0.2 & 0.8 & 1.8 & 1.4 & 1.0 & 1.4 & 0.0 & 0.2 & 0.9 & 0.6 & 0.71 \\
\hline Apr & 0.5 & 0.5 & 0.9 & 1.0 & 0.0 & 1.0 & 2.2 & 2.0 & 1.5 & 1.1 & 0.8 & 0.9 & 0.7 & 1.0 & 0.71 \\
\hline Jul & 0.2 & 0.4 & 0.9 & 1.5 & 0.8 & 1.1 & 1.8 & 2.0 & 1.9 & 1.4 & 0.3 & 1.0 & 0.9 & 1.3 & 0.71 \\
\hline Aug & 0.2 & 0.8 & 0.9 & 1.1 & 1.2 & 1.3 & 1.9 & 2.0 & 1.8 & 1.7 & 0.7 & 1.3 & 0.5 & 0.9 & 0.86 \\
\hline$n>d$ & \multicolumn{2}{|c|}{0.83} & \multicolumn{2}{|c|}{0.86} & \multicolumn{2}{|c|}{0.83} & \multicolumn{2}{|c|}{0.33} & \multicolumn{2}{|c|}{0.33} & \multicolumn{2}{|c|}{0.80} & \multicolumn{2}{|c|}{0.60} & \\
\hline
\end{tabular}

fasciatus, L. moretoniensis and $M$. chinensis were significantly higher by night than by day $(p<0.05)$ (Tables 1 \& 2).

\section{Recruitment}

Patterns of catches of small fish $1<5 \mathrm{~cm}$ standard length, SL) indicated that recruitment to the area was seasonal in Pelates quadrilineatus and Leiognathus moretoniensis (October or earlier, and DecemberFebruary respectively), but protracted in Monacanthus chinensis and Apogon fasciatus (February-August and December-August respectively) (Fig. 3). Small

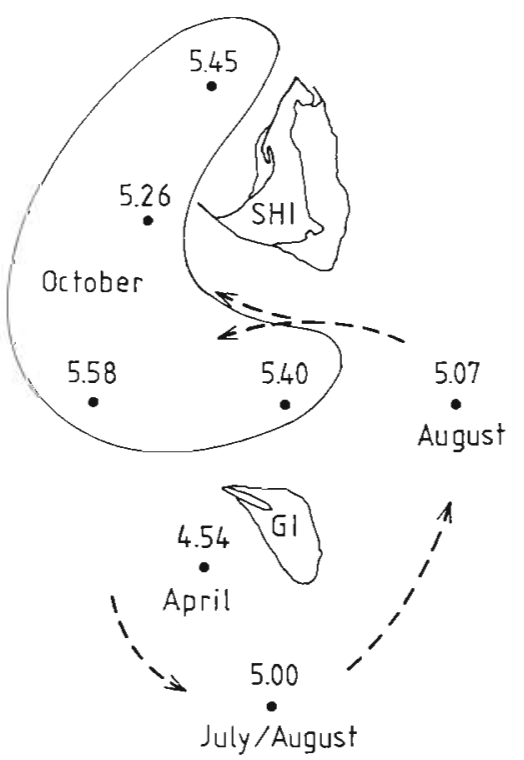

Fig. 2. Apogon fasciatus. Possible local ontogenetic migration pattern. Values shown at each site are overall mean standard lengths (cm, means of haul means) for the whole year. Months when highest mean densities were recorded in each area are also shown (enclosed zone is where highest densities occurred in October). SHI: St. Helena Island; GI: Green Island
( 4 to $5 \mathrm{~cm}$ ) Paramonacanthus otisensis were present throughout the year, which suggests continuous recruitment.

\section{Emigration}

The extent to which the density of fish in different cohorts declined with time suggested that the study species (except perhaps Apogon fasciatus) migrated through the area. Pauly (1981) compiled values of natural mortality $(M)$ for 175 fish stocks, and his list may be used to derive first order estimates of the probability of observing $M$ above a given value. Although rates of natural mortality should be relatively high among juveniles, the rates of numerical decline noted here were very high relative to most recorded values of $M$ (Table 4), and therefore probably reflected emigration as well as mortality. As the area was closed to commercial trawling, fishing mortality was not believed to be significant. The rate of decline was particularly high for Leiognathus moretoniensis, indicating that its mean residence time may have been lower than for the other species.

\section{Diets}

Gravimetric and numerical assessments of diets gave complementary results. In terms of weight, the main diet types were: Apogon fasciatus: carid and penaeid shrimps, isopods, polychaetes, brachyurans, teleosts; Paramonacanthus otisensis: bivalves, ophiuroids, polychaetes, unidentified crustaceans; Monacanthus chinensis: vegetation, polychaetes, gastropods, bivalves; Leiognathus moretoniensis: polychaetes, ophiuroids, calanoid copepods; Pelates quadrilineatus: polychaetes, bivalves, calanoids, amphipods (Table 5). In numerical terms, the main diet types were: $A$. fasciatus: amphipods, calanoids ${ }_{i} P$. otisensis: calanoids, am- 

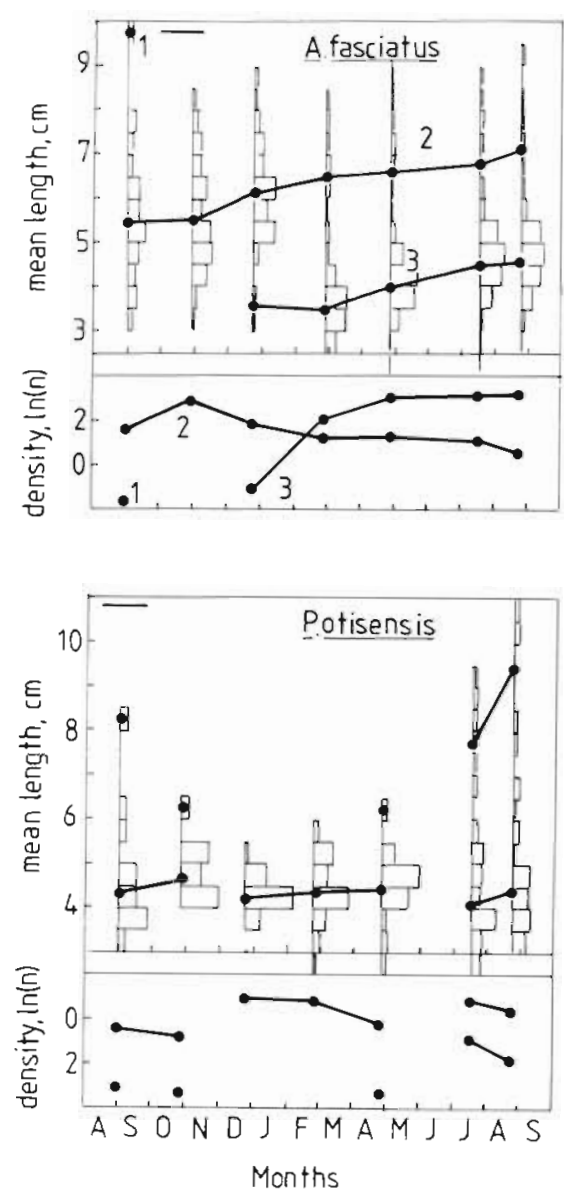
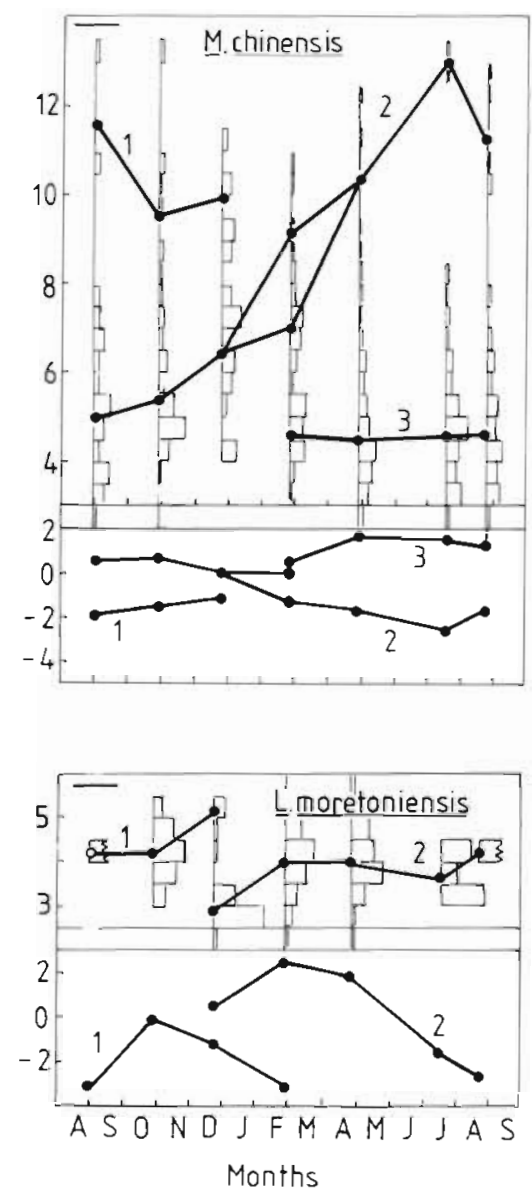

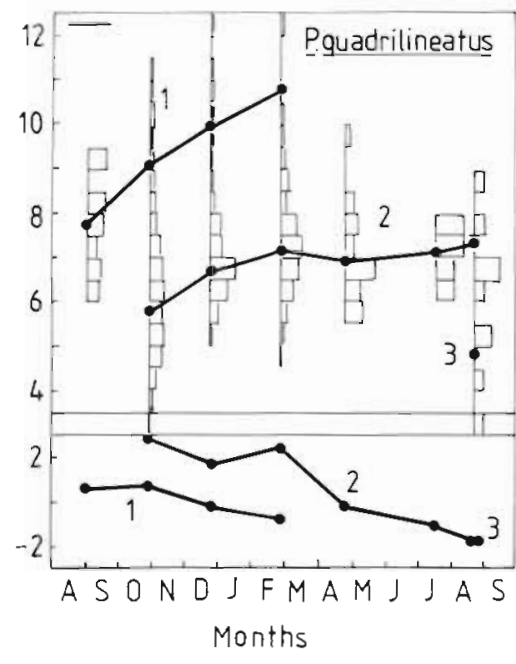

Fig. 3. Apogon fasciatus, Paramonacanthus otisensis, Monacanthus chinensis, Lelognathus moretoniensis, Pelates quadrilineatus. Recruitment patterns and seasonal changes in mean length (standard length, $\mathrm{cm}$ ) and density [log (no. haull $\left.\left.{ }^{-1}\right)\right]$ of cohorts separated by modal analysis. Population percentage lengthfrequency compositions are also shown; scale bar (top left) represents $50 \%$ contribution. Cohorts are indicated by numbers phipods; $M$. chinensis: calanoids, gastropods, amphipods; L. moretoniensis and $P$. quadrilineatus: calanoids, harpactacoids (Table 6). In terms of percentage occurrence, the main components of the diet were: A. fasciatus: amphipods, polychaetes, calanoids, isopods; $P$. otisensis: amphipods, calanoids, polychaetes, bivalves, ophiuroids; $M$. chinensis: vegetation, gastropods, calanoids, amphipods; L. moretoniensis: poly-

Table 4. Calculated instantaneous rates of numerical decline for population cohorts, with estimated probabilities that the observed rates are attributable to natural mortality $(M)$. Probabilities (i.e. the proportion of all fish stocks having $M$ values greater than an observed rate of decline) are based on frequencies of $M$ tabulated by Pauly (1981) and are indicative only. Cohorts are numbered as in Fig. 3

\begin{tabular}{|lccccccc|}
\hline Species & Estimated rates of decline & \multicolumn{3}{c}{$p(M)$} & \\
& \multicolumn{3}{c}{ Cohort } & & Cohort & \\
& 1 & 2 & 3 & 1 & 2 & 3 \\
\hline Lelognathus moretoniensis & 9.1 & 11.6 & - & 0 & 0 & - \\
Pelates quadrilineatus & 3.2 & 5.8 & - & 0.04 & 0.01 & - \\
Monacanthus chinensis & - & 3.7 & - & - & 0.03 & - \\
Apogon fasciatus & - & 2.3 & - & - & 0.06 & - \\
\hline
\end{tabular}

chaetes, calanoids, ophiuroids, harpactacoids, bivalves; P. quadrilineatus: calanoids, ostracods, amphipods, gastropods, bivalves (Table 7 ).

Cluster analysis of the percentage occurrence and gravimetric data indicated that the diets of the 2 monacanthid species were relatively similar, and that they were closer to the diet of Pelates quadrilineatus than to those of the remaining 2 species (Fig. 4). However, the numerical diet analysis differed in giving 2 main clusters, namely Apogon fasciatus/Paramonacanthus otisensis and $P$. quadrilineatus/Leiognathus moretoniensis, these groups having affinities with large and small Monacanthus chinensis respectively. A. fasciatus had the most distinctive diet and ate a wide size range of prey (including other fish, such as gobies and leiognathids). Cluster analysis of the same data sets, but after omission of the 'unidentified' food category, yielded results very similar to those described above.

Cluster analysis also revealed that, 
in general, interspecific differences in diet were greater than differences between size classes of the same species (Fig. 4). Mean intraspecific dietary overlap was greater than mean interspecific overlap, which did not exceed $60 \%$ (Table 8). Interspecific dietary overlap (weight-based) was greatest between larger fish (Table 8). Ontogenetic diet shifts were most marked in Leiognathus moretoniensis and
Monacanthus chinensis (Fig. 4). In all species there was a reduction in the relative consumption of copepods (mainly calanoids, but harpactacoids also in the case of $L$. moretoniensis) as body size increased (Tables 5 to 7 ). At the same time, dependence on alternative prey types rose, notably polychaetes (Paramonacanthus otisensis, Monacanthus chinensis), amphipods ( $P$. quadrilineatus, L. moretoniensis), crabs,

Table 5. Two-way diet classification (percentage composition by dry weight) based on cluster analysis. Groups are separated at dissimilarity levels of 0.35 (predators) and 0.80 (prey). Species abbreviations; lower case, small fish; upper case, large fish; Af: Apogon fasciatus; Lm: Leiognathus moretoniensis; Mc: Monacanthus chinensis; Po: Paramonacanthus otisensis; Pq: Pelates quadrilineatus; Unid.: unidentified

\begin{tabular}{|c|c|c|c|c|c|c|c|c|c|c|}
\hline \multirow[t]{2}{*}{ Prey type } & \multicolumn{10}{|c|}{ Predator group } \\
\hline & $a f$ & $A F$ & PO & $P Q$ & $p q$ & $m c$ & $M C$ & po & $L M$ & $\operatorname{lm}$ \\
\hline Sergestids & 0.60 & 0.44 & - & 0.05 & - & - & - & 0.20 & - & 0.08 \\
\hline Tanaids & 0.98 & 0.32 & - & 0.14 & 0.10 & 0.38 & 0.14 & 0.21 & - & - \\
\hline Mysids & 2.22 & 1.04 & - & 0.22 & - & 0.02 & - & 0.02 & - & - \\
\hline Thalassids & 1.14 & 1.22 & - & - & - & - & - & - & - & - \\
\hline Stomatopods & 0.48 & 1.72 & - & - & - & 0.10 & - & - & - & - \\
\hline Sponges & - & 0.29 & - & - & - & - & - & - & - & - \\
\hline Gastropods & 0.05 & 0.07 & 1.59 & 1.70 & 0.57 & 6.80 & 4.16 & 3.42 & - & 0.16 \\
\hline Sediment & 0.30 & 0.21 & 0.85 & 0.24 & - & 5.14 & 5.57 & 2.74 & - & 0.44 \\
\hline Plant material & - & 0.26 & 0.36 & 0.48 & - & 18.81 & 10.00 & 2.13 & - & - \\
\hline Bivalves & 1.54 & 3.73 & 21.60 & 4.19 & - & 1.28 & 6.82 & 12.01 & 4.07 & 1.60 \\
\hline Ophiuroids & - & 0.22 & 4.79 & 0.41 & - & 1.11 & 1.58 & 12.38 & 23.81 & 1.69 \\
\hline Amphipods & 14.55 & 5.74 & 2.20 & 3.70 & 0.94 & 3.59 & 5.16 & 4.08 & 7.26 & 0.19 \\
\hline Unid crustacea & 7.58 & 6.37 & 1.13 & 2.85 & 4.06 & 6.62 & 1.96 & 10.58 & 0.35 & 1.76 \\
\hline Calanoids & 1.00 & 2.53 & 1.92 & 4.21 & 12.93 & 4.26 & 0.39 & 2.83 & 3.94 & 12.74 \\
\hline Polychaetes & 10.45 & 13.12 & 4.61 & 9.04 & 7.50 & 3.44 & 10.85 & 5.01 & 20.40 & 53.33 \\
\hline Brachyurans & 2.70 & 16.40 & 0.58 & 3.26 & - & - & 0.07 & - & - & 0.34 \\
\hline Carids & 8.14 & 20.63 & 0.22 & 2.57 & - & - & - & - & - & - \\
\hline Penaeids & 3.62 & 8.10 & - & 0.40 & - & - & - & 0.20 & - & - \\
\hline Teleosts & 5.03 & 10.95 & 0.36 & 1.65 & - & 0.49 & 0.24 & 0.85 & - & - \\
\hline Isopods & 36.39 & 2.02 & 0.37 & 0.02 & - & 0.11 & 0.11 & 0.79 & - & 0.36 \\
\hline Unid. material & 2.92 & 4.35 & 59.55 & 56.52 & 73.66 & 47.55 & 48.34 & 41.60 & 40.18 & 24.77 \\
\hline Amphineurans & - & - & - & 0.02 & - & - & - & - & - & - \\
\hline Cumaceans & - & - & - & 0.02 & 0.01 & - & - & - & - & - \\
\hline Crab larvae & - & - & - & 0.06 & - & $=$ & - & - & - & - \\
\hline Unid. mollusca & 0.03 & 0.07 & - & 2.63 & - & 0.04 & 1.28 & - & - & - \\
\hline Opisthobranchs & - & - & - & 1.73 & - & - & - & - & - & - \\
\hline Cirripedes & - & - & - & 0.69 & - & - & 0.03 & - & - & - \\
\hline Harpactacoids & 0.02 & 0.05 & - & 0.46 & - & - & - & - & - & 2.33 \\
\hline Ostracods & 0.10 & 0.01 & - & 0.20 & 0.22 & 0.09 & 0.08 & 0.78 & - & 0.74 \\
\hline Anthozoans & - & - & - & 0.13 & - & 0.57 & 0.09 & - & - & - \\
\hline Ctenophores & - & - & - & - & - & 0.18 & 0.02 & - & - & - \\
\hline Insects & - & - & - & 0.02 & - & - & 0.04 & - & - & - \\
\hline Squid & - & - & - & - & - & - & 0.05 & - & - & - \\
\hline Fish scales & 0.02 & - & - & - & - & - & 0.17 & - & - & - \\
\hline Octopus & - & - & - & - & - & - & 0.24 & - & - & - \\
\hline Pteropods & - & - & - & 0.12 & - & -- & 0.26 & - & - & - \\
\hline Forams & - & 0.12 & - & 0.20 & - & - & 0.44 & 0.09 & - & 0.04 \\
\hline Echinoids & - & - & - & - & - & - & 1.63 & - & - & - \\
\hline
\end{tabular}


carids and teleosts (Apogon fasciatus), gastropods ( $P$. quadrilineatus) and ophiuroids ( $L$. moretoniensis) (Tables 5 to 7 ).

The results of gut content analysis for some fish species suggested that densities of prominent prey types varied significantly between sites: e.g. bivalves were taken by Paramonacanthus otisensis mainly at Sites $A$, $B$ and $C(p<0.01)$, and polychaetes were taken by Apogon fasciatus mainly at Site B $(p<0.05)$. Feeding intensity, as indicated by gut fullness, was greater by day than by night in Leiognathus moretoniensis, P. otisensis and $A$. fasciatus $(p<0.05)$ in each case). This was reflected in higher daytime numbers of important prey types: e.g. calanoids (for $L$. moretoniensis, $P$. otisensis and A. fasciatus; $\mathrm{p}<0.05$ in each case), amphipods (for Monocanthus chinensis and A. fasciatus: $p<0.05$ in both cases) and bivalves (for $P$. otisensis; $\mathrm{p}<0.01$ ).

The diet breadths of Leiognathus moretoniensis and Pelates quadrilineatus varied little through the year,

Table 6. Two-way diet classification (percentage composition by number) based on cluster analysis. Groups are separated at dissimilarity levels of 0.35 (predators) and 0.80 (prey). Abbreviations as in Table 5

\begin{tabular}{|c|c|c|c|c|c|c|c|c|c|c|}
\hline \multirow[t]{2}{*}{ Prey type } & \multicolumn{10}{|c|}{ Predator group } \\
\hline & $A F$ & af & $M C$ & PO & po & $p q$ & $P Q$ & $m c$ & $L M$ & $l m$ \\
\hline Harpactacoids & 0.09 & 0.09 & - & - & - & - & 12.42 & - & - & 25.52 \\
\hline Calanoids & 8.44 & 34.94 & 20.57 & 27.44 & 37.06 & 88.63 & 55.83 & 57.82 & 44.45 & 49.81 \\
\hline Amphipods & 31.74 & 28.05 & 26.48 & 32.32 & 18.73 & 0.95 & 7.78 & 6.58 & 5.56 & 0.28 \\
\hline Unid. material & 6.43 & 3.31 & 10.39 & 11.59 & 11.44 & 5.95 & 3.84 & 7.06 & 16.67 & 14.60 \\
\hline Gastropods & 1.56 & 0.29 & 20.79 & 6.10 & 10.10 & 0.54 & 5.90 & 16.22 & - & 0.19 \\
\hline Mysids & 12.26 & 6.42 & - & - & 0.13 & - & 0.14 & 0.07 & - & - \\
\hline Teleosts & 2.09 & 0.90 & 0.55 & 1.22 & 0.52 & - & 0.01 & 0.14 & - & - \\
\hline Sergestids & 2.43 & 3.82 & - & - & 0.26 & - & 0.01 & - & - & 0.09 \\
\hline Isopods & 4.17 & 4.39 & 0.22 & 1.22 & 2.34 & - & 0.07 & 0.27 & - & 0.19 \\
\hline Carids & 5.13 & 2.03 & - & 0.61 & - & - & 0.40 & - & - & - \\
\hline Brachyurans & 4.26 & 0.80 & 0.11 & 0.61 & - & - & 0.11 & - & - & 0.28 \\
\hline Ophiuroids & 0.09 & - & 0.33 & 4.27 & 2.60 & - & 0.07 & 0.21 & 11.11 & 0.47 \\
\hline Bivalves & 2.96 & 1.09 & 2.74 & 4.27 & 5.20 & - & 2.09 & 0.89 & 5.56 & 0.94 \\
\hline Unid. crustacea & 6.52 & 6.37 & 1.31 & 1.22 & 2.86 & 0.27 & 0.86 & 0.82 & 5.56 & 0.94 \\
\hline Polychaetes & 7.65 & 4.30 & 2.19 & 6.10 & 1.56 & 0.27 & 0.96 & 1.03 & 11.11 & 5.46 \\
\hline Plant material & 0.43 & - & 5.80 & 1.22 & 2.21 & - & 0.21 & 3.57 & - & - \\
\hline Sediment & 0.09 & 0.19 & 1.42 & 1.22 & 0.91 & - & 0.04 & 0.62 & - & 0.09 \\
\hline Forams & 0.17 & 0.05 & 1.09 & 0.61 & 1.95 & 0.27 & 1.49 & - & - & 0.19 \\
\hline Tanaids & 0.96 & 1.42 & 1.20 & - & 0.65 & 0.81 & 1.23 & 2.74 & - & - \\
\hline Ostracods & 0.17 & 0.38 & 2.41 & - & 1.04 & 2.17 & 6.17 & 1.65 & - & 0.94 \\
\hline Pteropods & - & - & 1.09 & - & - & - & 0.09 & - & - & - \\
\hline Penaeids & 1.22 & 0.67 & - & - & 0.13 & - & 0.02 & - & - & - \\
\hline Thalassids & 0.17 & 0.19 & - & - & - & - & - & - & - & - \\
\hline Stomatopods & 0.61 & 0.19 & - & - & - & - & - & 0.07 & - & - \\
\hline Sponges & 0.09 & - & - & - & - & - & - & - & - & - \\
\hline Crab larvae & 0.09 & -- & - & - & - & - & 0.01 & - & - & - \\
\hline Ctenophores & - & - & 0.11 & - & - & - & - & 0.21 & - & - \\
\hline Fish scales & - & 0.09 & 0.11 & - & - & - & - & - & - & - \\
\hline Anthozoans & - & - & 0.11 & - & - & - & 0.01 & 0.07 & - & - \\
\hline Cirripedes & - & - & 0.11 & - & - & - & 0.01 & - & - & - \\
\hline Squid & - & - & 0.11 & - & - & - & - & - & - & - \\
\hline Octopus & - & - & 0.11 & - & - & - & - & - & - & - \\
\hline Echinoids & - & - & 0.33 & - & - & - & - & - & - & - \\
\hline Unid. mollusca & 0.17 & 0.05 & 0.33 & - & - & - & 0.02 & 0.07 & - & - \\
\hline Opisthobranchs & - & - & - & - & - & - & 0.09 & - & - & - \\
\hline Cumaceans & - & - & - & - & - & 0.14 & 0.08 & - & - & -- \\
\hline Insects & - & - & - & - & - & - & 0.01 & - & - & - \\
\hline Scaphopods & - & - & - & - & - & - & 0.02 & - & - & - \\
\hline Amphineurans & - & - & - & - & - & - & 0.03 & - & - & - \\
\hline
\end{tabular}


but the diets of the leatherjackets were broadest in summer (Fig. 5). For most species, diet breadths varied little between sites, although they were greater (by weight) at Site A (Fig. 6). However, weight-based Apogon fasciatus diets tended to broaden where those of the other species narrowed [product-moment correlation, $r=-0.900 ; p<0.01$ (weight); $r=-0.524 ; p<0.10$ (number); $\mathrm{n}=7 \mid$ (Fig. 6). In all species except Paramonacanthus otisensis, diets broadened with increasing body size (Table 9 ).

\section{Patterns of resource use}

Plots of food and habitat resource use (Fig. 7) suggested niche complementarity. Species with similar diets (Pelates quadrilineatus / Leiognathus moretoniensis; Monacanthus chinensis/Paramonacanthus otisensis) had different spatial distributions. The peak densities of $P$. quadrilineatus and $L$. moretoniensis were seasonally distinct (Table 1). In contrast, Apogon fasciatus was relatively generalised in terms of diet, sea-

Table 7. Two-way diet classification (\% occurrence) based on cluster analysis. Groups are separated at dissimilarity levels of 0.35 (predators) and 0.80 (prey). Abbreviations as in Table 5

\begin{tabular}{|c|c|c|c|c|c|c|c|c|c|c|}
\hline \multirow[t]{2}{*}{ Prey type } & \multicolumn{10}{|c|}{ Species } \\
\hline & po & $P O$ & $m c$ & $M C$ & $p q$ & $P Q$ & af & $A F$ & $\operatorname{lm}$ & $L M$ \\
\hline Sponges & - & - & - & - & - & - & - & 0.1 & - & - \\
\hline Fish scales & - & - & 0.5 & - & - & - & 0.2 & - & - & - \\
\hline Sergestids & 0.8 & - & - & - & - & 0.2 & 2.3 & 1.0 & 0.2 & - \\
\hline Penaeids & 0.4 & - & - & - & - & 0.4 & 0.3 & 1.5 & - & - \\
\hline Thalassids & - & - & - & - & - & - & 0.5 & 0.3 & - & - \\
\hline Stomatopods & - & - & 0.4 & - & - & - & 0.5 & 0.8 & - & - \\
\hline Ophiuroids & 7.8 & 10.9 & 2.2 & 1.4 & 0.0 & 1.6 & 0.0 & 0.1 & 1.1 & 10.0 \\
\hline Unid crustacea & 9.0 & 3.1 & 6.2 & 4.3 & 4.5 & 9.1 & 15.6 & 10.5 & 1.7 & 5.0 \\
\hline Amphipods & 14.5 & 14.1 & 13.8 & 15.1 & 9.1 & 27.4 & 29.8 & 22.5 & 0.7 & 5.0 \\
\hline Polychaetes & 4.7 & 15.6 & 6.7 & 11.4 & 4.5 & 18.3 & 11.0 & 12.6 & 12.7 & 10.0 \\
\hline Bivalves & 8.6 & 10.9 & 4.9 & 11.4 & - & 24.3 & 2.7 & 5.0 & 2.2 & 5.0 \\
\hline Unid material & 32.5 & 29.7 & 40.9 & 34.6 & 63.6 & 69.0 & 8.2 & 10.8 & 10.3 & 15.0 \\
\hline Calanoids & 12.5 & 9.4 & 21.3 & 9.5 & 29.5 & 43.9 & 10.1 & 3.4 & 9.6 & 5.0 \\
\hline Plant material & 6.7 & 3.1 & 24.9 & 28.9 & - & 5.3 & - & 0.7 & - & - \\
\hline Gastropods & 8.6 & 7.8 & 27.6 & 17.5 & 6.8 & 26.9 & 0.3 & 0.4 & 0.4 & - \\
\hline Harpactacoids & - & - & - & - & - & 12.7 & 0.1 & 0.1 & 7.4 & - \\
\hline Ostracods & 2.4 & - & 3.1 & 4.3 & 15.9 & 22.7 & 0.6 & 0.3 & 2.0 & - \\
\hline Forams & 3.9 & 1.6 & 0.0 & 3.3 & 4.5 & 14.9 & 0.1 & 0.3 & 0.4 & - \\
\hline Tanaeids & 1.6 & - & 7.6 & 1.9 & 2.3 & 4.2 & 2.4 & 1.0 & - & - \\
\hline Sediment & 2.7 & 3.1 & 4.0 & 6.2 & - & 0.9 & 0.5 & 0.1 & 0.7 & - \\
\hline Teleosts & 1.6 & 3.1 & 1.3 & 1.4 & - & 0.2 & 1.7 & 2.8 & - & - \\
\hline Isopods & 3.5 & 3.1 & 1.8 & 0.9 & - & 1.1 & 6.8 & 5.0 & 0.4 & - \\
\hline Mysids & 0.4 & - & 0.4 & - & - & 2.7 & 5.2 & 5.3 & - & - \\
\hline Carids & - & 1.6 & - & - & - & 5.1 & 3.3 & 5.2 & - & - \\
\hline Brachyurans & - & 1.6 & - & 0.5 & - & 2.7 & 1.8 & 5.6 & 0.7 & - \\
\hline Amphineurans & - & - & - & - & - & 0.7 & - & - & - & - \\
\hline Opisthobranchs & - & - & - & - & - & 1.6 & - & - & - & - \\
\hline Cumaceans & - & - & - & - & - & 1.1 & - & - & - & - \\
\hline Insects & - & - & - & - & - & 0.2 & - & - & - & - \\
\hline Crab larvae & - & - & - & - & - & 0.2 & - & 0.1 & - & - \\
\hline Pteropods & - & - & - & 0.9 & - & 0.7 & - & - & - & - \\
\hline Echinoids & - & - & 0.4 & 1.4 & - & - & - & - & - & - \\
\hline Unid mollusca & - & - & 0.4 & 1.4 & - & 0.4 & 0.1 & 0.3 & - & - \\
\hline Anthozoans & - & - & 0.4 & 0.5 & - & 0.2 & - & - & - & - \\
\hline Cirripedes & - & - & - & 0.5 & - & 0.2 & - & - & - & - \\
\hline Squid & - & - & - & 0.5 & - & - & - & - & - & - \\
\hline Octopus & - & - & - & 0.5 & - & - & - & - & - & - \\
\hline Ctenophores & - & - & - & 0.5 & - & - & - & - & - & - \\
\hline
\end{tabular}




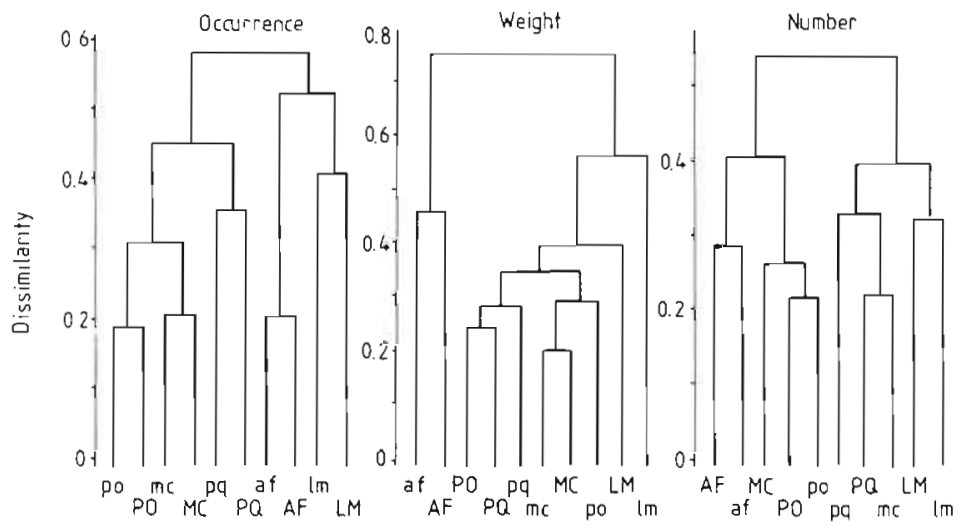

Fig. 4. Relationships revealed by cluster analysis of frequency of occurrence, gravimetric and numerical diet data. Af: Apogon fasciatus; Lm: Leiognathus moretoniensis; Mc: Monacanthus chinensis; Po: Paramonacanthus otisensis; Pq: Pelates quadrilineatus. Lower case: small fish (standard length $<5 \mathrm{~cm}$ ); upper case: large fish

Table 8. Inter- and intra-specific dietary overlap (Schoener's $D$ ) between small and large fish (means and standard errors), based on gravimetric and numeric diet analyses

\begin{tabular}{|ccc|}
\hline Comparison & $\begin{array}{c}\text { Gravimetric } \\
(\bar{x} \pm \mathrm{SE})\end{array}$ & $\begin{array}{c}\text { Numeric } \\
(\bar{x} \pm \mathrm{SE})\end{array}$ \\
\hline Interspecific & & \\
Small-Small & $38.90 \pm 5.92$ & $56.20 \pm 3.20$ \\
Large-Large & $51.60 \pm 6.54$ & $51.00 \pm 4.26$ \\
Small-Large & $44.20 \pm 4.37$ & $50.65 \pm 3.85$ \\
Intraspecific & & \\
Small-Large & $66.20 \pm 5.51$ & $68.40 \pm 2.89$ \\
\hline
\end{tabular}

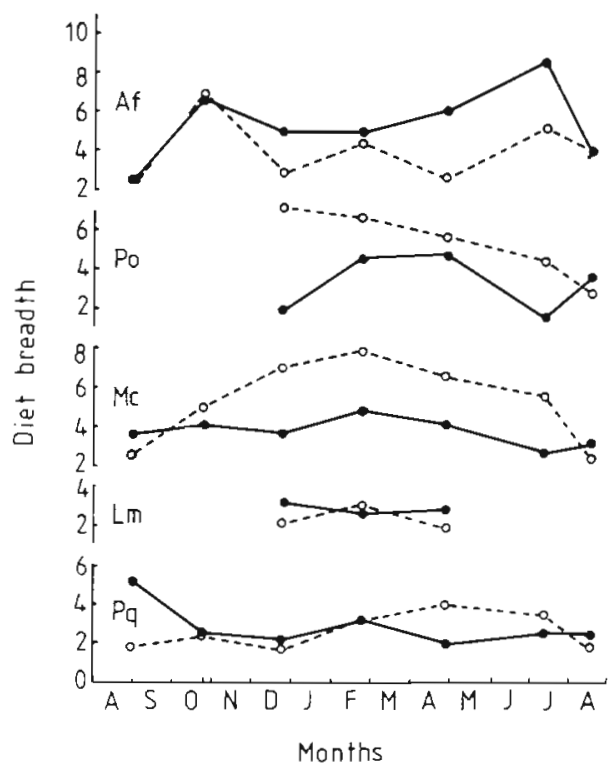

Fig. 5. Seasonal variations in diet breadth (Levins' B), based on numerical diet analyses $(0)$ and gravimetric analysis $(\bullet)$. Species abbreviations as in Fig. 4 sonality and distribution. However, significant overlap in interspecific resource use was more prevalent than was separation (Table 10). Instances of separation involved L. moretoniensis (from A. fasciatus in terms of food, from $M$. chinensis in habitat and from $P$. quadrilineatus in time).

\section{DISCUSSION}

The abundant species in this study have also featured strongly in other ecological studies of Moreton Bay and northern Australia. In Moreton Bay, Leiognathus moretoniensis, Paramonacanthus oblongus (= otisensis) and Apogon fasciatus were the most common species recorded by Stephenson et al. (1982b), and ail 5 species except Monacanthus chinensis were prominent (in similar proportions to those in local trawler catches) in the diets of local piscivorous birds examined by Blaber $\&$ Wassenberg (1989). The same or related species are also abundant in the southeast Gulf of Carpentaria (Rainer 1984, Blaber et al. 1990).

The importance of subtidal macrophyte beds as habitats for young marine fish is indicated by 4 of the 5 study species occurring in greatest densities at the most vegetated site. This habitat association was strongest for Monacanthus chinensis and Pelates quadrilineatus, and similar preferences have been recorded for these species by Larkum (1976), Bell et al. (1978), Young \& Wadley (1979) and Blaber \& Blaber (1980). However, there was evidence that fish emigrated from the area as they grew. Adult $P$. quadrilineatus, Leiognathus spp., Paramonacanthus otisensis and

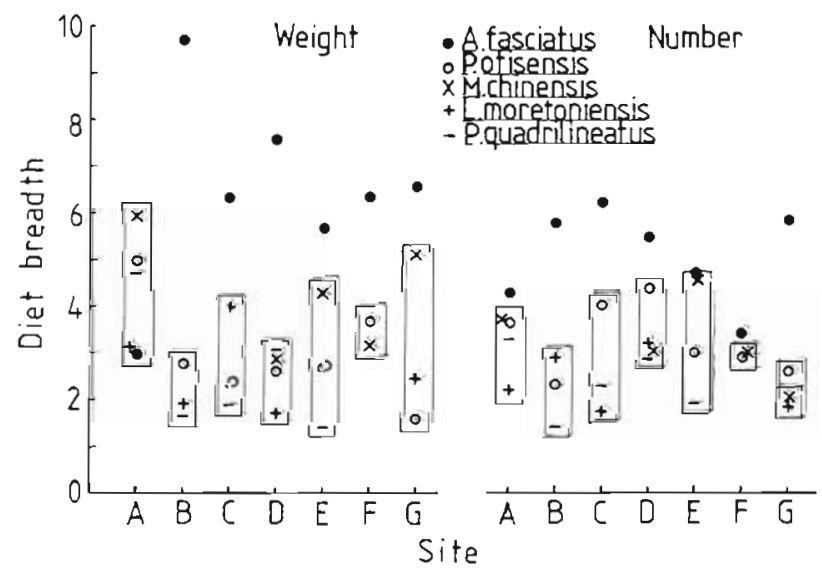

Fig. 6. Site-related variations in diet breadth (Levins' B), based on numerical and gravimetric diet analyses. For clarity, values for all species except Apogon fasciatus have been boxed (see text). Species abbreviations as in Fig. 4 
M. chinensis occur in deeper or offshore waters (Blaber \& Blaber 1980, Rainer 1984, Blaber et al. 1990). In contrast, Lovamia fasciata (= A. fasciatus) is largely confined to relatively shallow water $(5$ to $9 \mathrm{~m}$ ) (Rainer 1984), a finding which supports the impression that this species was the least migratory of those studied: there were signs of a local ontogenetic migration, but it was less clearly depth-related than in the other species and could result from changing habitat preferences with age. Increased residence time may also contribute to the relatively high abundance of $A$. fasciatus.

The seasonality of Pelates quadrilineatus and Leiognathus moretoniensis was very pronounced, with the highest numbers occurring in October-February and February-April respectively. Young \& Wadley (1979) and Young (1981) also found strong seasonality in $P$. quadrilineatus, with a November-March peak. However, Blaber \& Blaber (1980) recorded a January-March $P$. quadrilineatus peak and Blaber \& Wassenberg (1989) found that piscivorous birds showed little seasonal variation in $P$. quadrilineatus consumption. Similarly, the abundance of $L$. moretoniensis peaked in different months in previous studies [e.g. early September (Stephenson et al. 1982b); January (Blaber \& Wassenberg 1989)]. Such differences presumably reflect variation in recruitment timing and the location and selectivity of sampling.

The 5 species shared a benthopelagic feeding habit, taking infauna (e.g. polychaetes and bivalves), epifauna (e.g. ophiuroids, isopods and amphipods) and zooplankton (e.g. calanoid copepods). Monacanthus chinensis also ate vegetation (the main dietary component by weight; see also Bell et al. (1978)]. The species differed in terms of the size of prey taken: Pelates quadrilineatus and Leiognathus moretoniensis concentrated on small or narrow-bodied items like calanoids, harpactacoids and polychaetes, $M$. chinensis and Paramonacanthus otisensis took more amphipods and molluscs, and Apogon fasciatus ate a wide size range of prey, including epibenthic shrimps, crabs and fish as well as amphipods and other small crustaceans. In general, dietary analysis by the frequency of occurrence method emphasised most of the prey types revealed as important by the numeric and gravimetric methods. However, it did not stress certain prey types

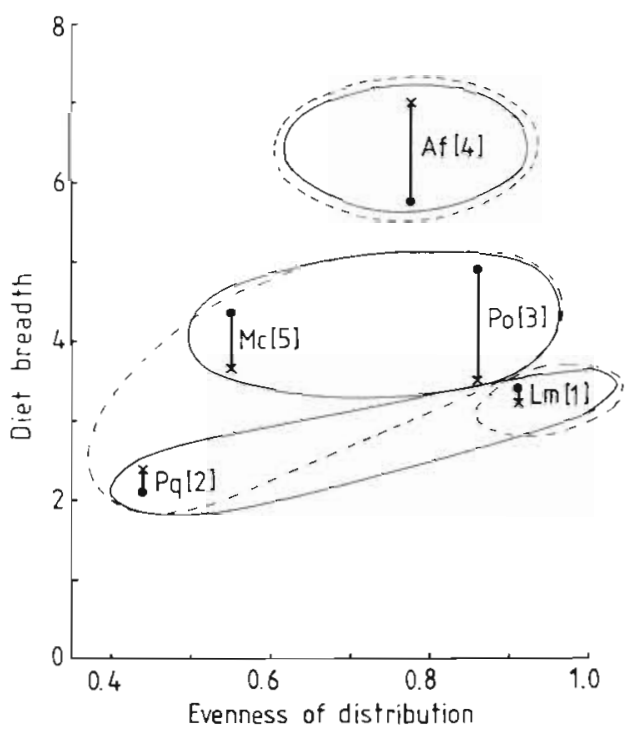

Fig. 7. Spacing of the 5 species along food, habitat and temporal dimensions. Main axes are diet breadth (Levins' $B$ ) and evenness of distribution among sites (Shannon's index). Ellipses surround species with similar diets, as indicated by dissimilarity criteria from cluster analysis of numeric $(-, \bullet)$ and gravimetric (---, ') diet data (Fig. 4). Numbers in brackets indicate ranks of increasing temporal evenness in catch Species abbreviations as in Fig. 4

which were ranked highly by the gravimetric approach, such as carids, penaeids, crabs and fish (Apogon fasciatus), polychaetes (Monacanthus chinensis, Pelates quadrilineatus) and bivalves ( $M$. chinensis). In part, this may have reflected a patchier distribution and/or lower availability of preferred, relatively large prey types.

Perusal of the groups delimited by the 3 cluster analyses of prey types (based on occurrence, numeric and gravimetric diet data; Tables 5 to 7) revealed the following patterns of association among the dominant prey types. Polychaetes, bivalves and ophiuroids, all strongly bottom-associated prey types, always occurred in the same prey group and were representative of prey vulnerable to sediment-feeding predators. A second association, between amphipods, calanoids and gastropods (and less consistently, harpactacoids), shared affinities with the first association, but appeared to reflect a more epifaunal or bentho-

Table 9. Diet breadth (Levins' $B$ ) for small and large fish, based on gravimetric and numeric diet analyses. Abbreviations as in Table 5

\begin{tabular}{|ccccccccccc}
\hline Analysis & \multicolumn{9}{c}{ Species } \\
& af & AF & po & PO & mC & $M C$ & Im & $L M$ & $p q$ & $P Q$ \\
\hline Weight & 5.45 & 8.51 & 4.51 & 2.46 & 3.60 & 3.72 & 2.75 & 3.73 & 1.76 & 2.97 \\
Number & 4.63 & 6.86 & 4.94 & 4.88 & 2.69 & 6.02 & 2.96 & 3.86 & 1.27 & 2.92 \\
\hline
\end{tabular}


pelagic habit. Vegetation tended to be grouped with either of these 2 associations. A third consistent association involved relatively large, mobile, epibenthic prey types (carids, crabs, teleosts and isopods). The existence of these associations suggested that an ability to exploit particular microhabitats and/or general prey characteristics was an important aspect of predator foraging. Such a strategy could permit efficient, flexible predation behaviour. Many fish species are opportunistic feeders, showing marked individual differences in patterns of prey consumption (Bryan \& Larkin 1972, Bres 1989) and an ability to respond to changes in food availability (e.g. Robertson 1987, Brewer \& Warburton 1988). There was evidence that the densities of important prey species such as bivalves and polychaetes varied significantly between locations. Pelates quadrilineatus took mainly polychaetes, copepods and bivalves, but elsewhere in Moreton Bay this species has been reported to concentrate on ostracods, amphipods, forams and tanaeids (Blaber \& Blaber 1980). Such flexible tactics allow fish to efficiently exploit available food and not rely on particular resources, which may become limiting. In situations where a large number of diet combinations can provide sufficient energy for growth and reproduction (Bres 1989), diet switching may be adaptive.

Cluster analysis revealed that diets of the 2 size classes of each predator species were similar when the analysis was based on a frequency of occurrence basis, but less so when based on numeric or gravimetric data. This suggested that the choice of prey types by a predatory species was relatively consistent, but that the proportional contribution of each type varied with body size. The most noticeable ontogenetic diet shift was a reduced consumption of copepods and a correspondingly stronger reliance on larger prey types, which differed according to the predator species.

Although fish often show marked ontogenetic changes in diet (Livingston 1988), ontogenetic variation in the groups sampled was less obvious than interspecific variation. Nevertheless, interspecific dietary overlap (by weight) was smaller in smaller fish, which were more abundant and presumably more concentrated than the dispersed adults. Four species exhibited diet expansion with increasing size. Ontogenetic trends in diet breadth are not consistent between fish species (Pearre 1986, Ross 1986).

Gut fullness and numerical diet analyses showed that feeding occurred mainly by day, diel differences being significant in all species except Pelates quadrilineatus. Conacher et al. (1979) reported Monacanthus chinensis as a daytime feeder in seagrass beds. It is unlikely that these fish undergo vertical movements into the water column at night, since catch rates were significantly higher by night. Previous workers have recorded higher catch rates both by night (e.g. Salzen 1957) and by day (e.g. Blaber et al. 1990). Diel behaviour appears to be habitat-dependent, at least in part: e.g. although many reef fish show clear lateral migration into nearby seagrass beds to feed at night (Ogden \& Ehrlich 1977, Robblee \& Zieman 1984), this is not necessarily true of fishes on shallow, seagrass-covered banks (Sogard et al. 1989). Possibly the species de-

Table 10. Overlap in resource use (Schoener's D). Results for food overlap are based on gravimetric and numeric analyses of diets. Summary columns give means and standard errors. Abbreviations as in Table 5

\begin{tabular}{|c|c|c|c|c|c|c|c|c|}
\hline \multicolumn{7}{|c|}{ Food } & & Number \\
\hline $\begin{array}{l}\frac{1}{5} \\
\frac{9}{0} \\
3\end{array}$ & $\begin{array}{l}\text { Species } \\
\text { Af } \\
P_{O} \\
M c \\
L m \\
P_{q}\end{array}$ & $\begin{array}{c}\text { Af } \\
\\
0.410 \\
0.442 \\
0.387 \\
0.509\end{array}$ & $\begin{array}{c}P_{0} \\
0.627 \\
\\
0.722 \\
0.437 \\
0.746\end{array}$ & $\begin{array}{l}M c \\
0.519 \\
0.773 \\
\\
0.433 \\
0.736\end{array}$ & $\begin{array}{c}L m \\
0.393 \\
0.541 \\
0.575 \\
\\
0.459\end{array}$ & $\begin{array}{c}P Q \\
0.439 \\
0.587 \\
0.676 \\
0.704 \\
\text { Overall }\end{array}$ & $\begin{array}{l}0.437 \pm 0.027 \\
0.579 \pm 0.090 \\
0.583 \pm 0.084 \\
0.429 \pm 0.01 .5 \\
0.613 \pm 0.075 \\
0.528 \pm 0.046\end{array}$ & $\begin{array}{l}0.495 \pm 0.052 \\
0.632 \pm 0.050 \\
0.636 \pm 0.056 \\
0.553 \pm 0.064 \\
0.602 \pm 0.060 \\
0.583 \pm 0.037\end{array}$ \\
\hline \multicolumn{8}{|c|}{ Habitat and time } & Time \\
\hline 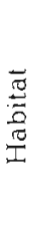 & $\begin{array}{l}\text { Species } \\
A f \\
P O \\
M C \\
L m \\
P q\end{array}$ & $\begin{array}{c}\text { Af } \\
\\
0.688 \\
0.677 \\
0.547 \\
0.637\end{array}$ & $\begin{array}{c}\text { Po } \\
0.669 \\
\\
0.595 \\
0.507 \\
0.433\end{array}$ & $\begin{array}{c}M C \\
0.803 \\
0.731 \\
\\
0.374 \\
0.829\end{array}$ & $\begin{array}{c}L m \\
0.402 \\
0.450 \\
0.523 \\
\\
0.409\end{array}$ & $\begin{array}{c}P q \\
0.473 \\
0.510 \\
0.525 \\
0.372 \\
\text { Overall }\end{array}$ & $\begin{array}{l}0.637 \pm 0.032 \\
0.556 \pm 0.055 \\
0.619 \pm 0.095 \\
0.459 \pm 0.041 \\
0.577 \pm 0.099 \\
0.570 \pm 0.045\end{array}$ & $\begin{array}{l}0.587 \pm 0.092 \\
0.590 \pm 0.066 \\
0.646 \pm 0.072 \\
0.437 \pm 0.033 \\
0.470 \pm 0.035 \\
0.546 \pm 0.045\end{array}$ \\
\hline
\end{tabular}


scribed here spend the day feeding in a range of habitats and settle demersally at night for shelter, resulting in high night-time catches

To some extent, observed changes in catch per unit effort will reflect changes in catchability rather than abundance. Catchability of these species is affected by differences in trawling technique (Warburton 1989). However, the influence of several important sources of catchability variation was minimised by operating the trawl from the same vessel at the same sites in a standard fashion. Catchability may be affected by differences in trawl visibility, but if visibility exerted a strong influence on catchability then it would be expected that mean catches would vary considerably by night and day. The ratios of night mean catch : day mean catch were 1.1 to 1.8 for 4 species and 5.1 for the fifth (Leiognathus moretoniensis) (from Table 1). Similar ratios (highest : lowest) for mean catches by site and trip tended to be much larger ( 6.9 to 349.5 and 4.2 to 272.2 respectively), suggesting that visibility exerted only a relatively minor influence on catches from different sites and seasons.

Niche overlap values (Table 10) showed there was some resource differentiation along the important dimensions of habitat, food and time. However, the average overlap values for the 3 dimensions were similar and relatively high, so scope existed for competitive interactions among members of the assemblage. The dynamics of resource overlap among these species await further investigation, since overlap can be both a cause and a consequence of interspecific competition (Holbrook \& Schmitt 1989), and food niches may contract or expand in response to variations in prey abundance (Harmelin-Vivien et al. 1989).

Responses to natural variation in prey availability may help explain why the diet breadths of Apogon fasciatus and more specialised species showed an inverse relationship: e.g. where prey diversity and abundance are high, different species may adopt different feeding strategies (Harmelin-Vivien et al. 1989). If, as seems to be the case, the feeding niche of $A$. fasciatus includes those of other species, the assemblage could include both specialists and generalists (Colwell \& Fuentes 1975). Given the potentially high food consumption by members of this community (e.g. the removal of about $50 \%$ of the standing crop of gammarid amphipods and 12 to $50 \%$ of carid shrimps by Monacanthus chinensis in Posidonia australis beds; Conacher et al. 1979), the effects of resource depletion by predators should be examined in more detail. Although choice of habitats and foods by a fish species can be modified substantially by interspecific interactions (Werner \& Hall 1979. Werner \& Mittelbach 1981) - which may have important ecological and fisheries implications (Werner 1980 ) - the significance and dynamics of such inter- actions remain almost unknown for most aquatic systems.

Acknowledgements. We are grateful to the trawler crew, Jack Kelly and Bill Hayes, for their help in carrying out the sampling programme. Special thanks are due to Alison Green for fieldwork and sample analysis and to Andrew Letchford for most of the gut-content analyses. We also thank David Brewer and Rachel Webb for assistance in data analysis, and Natalie Gorman and Geoff Carey for help with sampling. The assistance of Peter Lennon (Queensland Department of Geographic Information) and Paul Luck (Queensland Department of Primary Industries) in giving access to satellite images and aerial photographs is acknowledged. Alan Cribb kindly identified the algae. Ian Poiner, Aubrey Harris and Vivienne Mawson provided helpful comments on the manuscript. The study was supported by a CSIRO/University of Queensland research grant.

\section{LITERATURE CITED}

Bell, J. D., Burchmore, J. J., Pollard, D. A. (1978). Feeding ecology of three sympatric species of leatherjackets (Pisces: Monacanthidae) from a Posidonia seagrass habitat in New South Wales. Aust. J. mar. freshwat. Res. 29: $631-643$

Blaber, S. J. M., Blaber, T. G. (1980). Factors affecting the distribution of juvenile estuarine and inshore fish. J. Fish Biol. 17: 143-162

Blaber, S. J. M., Brewer, D. T., Salini, J P., Kerr, J. (1990). Biomasses, catch rates and patterns of abundance of demersal fishes, particularly predators of prawns, in a tropical bay in the Gulf of Carpentaria, Australia, Mar. Biol. 107: $397-408$

Blaber, S. J. M., Wassenberg, T. J. (1989). Feeding ecology of the piscivorous birds Phalacrocorax varius, $P$. melanoleucos and Sterna bergii in Moreton Bay, Australia: diets and dependence on trawler discards. Mar. Biol. 101: 1-10

Bres, M. (1989). The effects of prey relative abundance and chemical cues on prey selection in rainbow trout. J. Fish Biol. 35: 439-445

Brewer, D. T., Warburton, K. (1988). A dietary study of Sillago analis and its variation in three Australian locations. Proc. Linn. Soc. N.S.W. 110: 212-213

Bryan, J. E., Larkin, P. A. (1972). Food specialisation by individual trout. J. Fish. Res. Bd Can. 29: 1615-1624

Cassie, R. M. (1954). Some uses of probability paper in the analysis of size frequency distributions. Aust. J. mar. freshwat. Res. 5: 513-522

Colwell, R. K., Fuentes, E. R. (1975). Experimental studies of the niche. A. Rev. Ecol. Syst. 6: 281-310

Conacher, M. J., Lanzing, W. J. R., Larkum, A. W. D. (1979) Ecology of Botany Bay. II. Aspects of the feeding ecology of the fanbellied leatherjacket, Monacanthus chinensis (Pisces: Monacanthidae), in Posidonia australis seagrass beds in Quibray Bay, Botany Bay, New South Wales. Aust. J. mar. freshwat. Res. 30: 387-400

Elliott, J. M. (1977). Some methods for the statistical analysis of samples of benthic invertebrates. Freshwat. biol. Ass. Sci. Publ. 25

Grant, E. M. (1982). Guide to fishes. Queensland Dept Harbours and Marine, Brisbane

Harmelin-Vivien, M. L., Kaim-Malka, R. A., Ledoyer, M., 
Jacob-Abraham. S. S. (1989). Food partitioning among scorpaenid fishes in Mediterranean seagrass beds. J. Fish Biol. 34: 715-734

Holbrook, S. J., Schmitt, R. J. (1989). Resource overlap, prey dynamics, and the strength of competition. Ecology 70 $1943-1953$

Hurlbert, S. H. (1978). The measurement of niche overlap and some relatives. Ecology 59:67-77

Hyland, S. J., Courtney, A. J., Butler, C. T. (1989). Distribution of seagrass in the Moreton Region form Coolangatta to Noosa. Queensland Dept of Primary Industries Informa. tion Service QI89010, Brisbane

Hyslop, E. J (1980). Stomach contents analysis - a review of methods and their application. J. Fish. Biol. 17: 411-429

Larkum, A. W. D. (1976). The ecology of Botany Bay. I. The growth of Posidonia australis (Brown) Hook f. in Botany Bay and other bays of the Sydney basin. Aust. J. mar. freshwat. Res. 27: 117-127

Levins, R. (1968). Evolution in changing environments Princeton University Press, Princeton

Linton, L. R., Davies, R. W., Wrona, F. J. (1981). Resource utilization indices: an assessment. J. Anim. Ecol. 50: 283-292

Livingston, R. J. (1988). Inadequacy of species-ievel designations for ecological studies of coastal migratory fishes. Environ. Biol. Fish. 22: 225-234

Mathur, D. (1977). Food habits and competitive relationships of the bandfin shiner in Halawakee Creek, Alabama. Am. Midl. Nat. 97: 89-100

Maxwell, W G. H. (1970). The sedimentary framework of Moreton Bay, Queensland. Aust. J. mar. freshwat. Res. 21 $71-88$

Odgen, J. C., Ehrlich, P. R. (1977). The behavior of heterotypic resting schools of juvenile grunts (Pomadasyidae). Mar. Biol. 42: 273-280

Parrish, J. D. (1989). Fish communities of interacting shallowwater habitats in tropical oceanic regions. Mar. Ecol. Prog. Ser. 58: 143-160

Pauly, D. (1981). On the interrelationships between natural mortality, growth parameters, and mean environmental temperature in 175 fish stocks. J. Cons. perm. int. Explor. Mer. 39: 175-192

Pearre, S. Jr (1986). Ratio-based trophic niche breadths of fish, the Sheldon spectrum, and the size-efficiency hypothesis. Mar. Ecol. Prog. Ser. 27: 299-314

Pielou, E. C. (1966). The measurement of diversity in different types of biological collections. J. theoret. Biol. 13: 131-144

Pollock, B. R., Williams. M. J. (1983). Assessment of the angling fishery for yellowfin bream. Acanthopagrus australıs (Gunther), in Moreton Bay, Australia. J Fish Biol. 22: $125-132$

Rainer, S. F. (1984). Temporal changes in a demersal fish and cephalopod community of an unexploited coastal area in Northern Australia. Aust. J. mar. freshwat. Res. 35: $747-768$

Robblee, M. B., Zieman, J. C. (1984). Diel variation in the fish fauna of a tropical seagrass feeding ground. Bull. mar. Sci. 34: $335-345$

Robertson, D. R. (1987). Responses of two coral reef toadfishes (Batrachoididae) to the demise of their primary prey, the sea urchin Diadema antillarum. Copeia 1987: 637-642

Ross, S. T (1986). Resource partitioning in fish assemblages: a review of field studies. Copeia 1986: 352-388

Salzen, E. A. (1957). A trawling survey off the Gold Coast. J. Cons. perm int. Explor. Mer 23: 72-82

Schoener, T W. (1986). The Anolis lizards of Bimini: resource partitioning in a complex fauna. Ecology 49: 704-726

Schoener, T. W. (1974). Resource partitioning in ecological cummunities. Science 185: 27-39

Sogard, M. Powell, G. V. N., Holmquist, J. G. (1989). Utilisation by fishes of shallow seagrass-covered banks in Florida Bay: 2. Diel and tidal patterns. Environ. Biol. Fish 24: $81-92$

Stephenson, W., Chant, D. C., Cook, S. D. (1982a). Trawled catches in Northern Moreton Bay. L. Effects of sampling variables. Mem. Queensl. Mus. 20: 375-386

Stephenson, W., Chant, D. C., Cook, S. D. (1982b). Trawled catches in Northern Moreton Bay. II. Changes over two years. Mem. Queensi. Mus. 20: 387-399

Stephenson, W., Williams, M. J. (1981). Analysis of south Queensland prawn catches landed at Queensland Fish Board depots. Proc. R. Soc. Queensl. 92: 57-74

Taylor, C. C. (1953). Nature of variability in trawl catches. Fish. Bull. U.S. 54: 145-166

Wallace, R. K. (1981). An assessment of diet-overlap indexes. Trans. Am. Fish. Soc. 110:72-76

Warburton, K. (1989). Catchability variation in short beam trawl hauls. Fish. Res. 7: 55-63

Wassenberg. T. J., Hill, B. J. (1989). The effect of trawling and subsequent handling on the survival of by-catch discarded from prawn trawlers in Moreton Bay, Australia. Fish. Res. 7: $99-110$

Werner, E. E. (1980). Niche theory in fisheries ecology. Trans. Am. Fish. Soc. 109: 254-260

Werner, E. E., Hall, D. J. (1979). Foraging efficiency and habitat switching in competing sunfishes. Ecology 60: $256-264$

Werner, E. E., Mittelbach, G. G. (1981). Optimal foraging: field tests of diet choice and habitat switching. Am. Zool. 21: $813-829$

Williams, M. J. (1980). Survey of fishing operations in Queensland. Queensl. Fish. Serv. Tech. Rep. No. 2

Young, P. C. (1981). Temporal changes in the vagile epibenthic fauna of two seagrass meadows (Zostera capricorni and Posidonia australis). Mar. Ecol. Prog. Ser. 5: 91-102

Young, P. C., Wadley, V. A. (1979). Distribution of shallowwater epibenthic macrofauna in Moreton Bay, Queensland, Australia. Mar. Biol. 53: 83-97

Zaret, I M., Rand, A. S. (1971). Competition in tropical stream fishes: support for the competitive exclusion principle. Ecology 52: $336-342$

Manuscript first received: June 27, 1990

Revised version accepted: November 16, 1992 